\title{
TRADE PRACTICE AND PRICE CONTROL IN THE ALCOHOLIC BEVERAGE INDUSTRY
}

\author{
Joe DE GanahL*
}

With Repeal came a new type of regulation in the alcoholic beverage industry. Pre-Prohibition legislation related principally to taxation and the regulation of the retail sale of alcoholic beverages in the social interest. There was no attempt to regulate the relationships between the retailer and his vendors.

The failure of this legislation was due in part to the failure to recognize the effects of industrial organization on the manufacture and sale of alcoholic beverages. With the rise of the large distilling and brewing corporations seeking new markets through high-pressure sales organizations, the independent tavernkeeper, theretofore subject to the restraints imposed by local legislation and local public opinion, ceased to exist. ${ }^{1}$ Among the devices used by the powerful sales organizations to achieve control of the local saloons was the furnishing of equipment, extension of credit, payment of rebates, and the rendering of liberal financial assistance in other ways. ${ }^{2}$

The resulting tied-house was one of the factors which brought the saloon into disrepute and helped to bring about Prohibition. ${ }^{3}$ This fact, emphasized in the studies of pre-Prohibition regulation, conducted in anticipation of Repeal, made it clear that post-Repeal legislation would have to embrace legislation controlling the relationships between manufacturers, importers, and wholesalers and retail establishments.

This type of legislation, however, had other roots quite distinct from the efforts to

*A.B., I925, Harvard University; J.D., I940, George Washington University. Member of District of Columbia Bar. Principal Enforcement Supervisor of former Federal Alcohol Administration. Now with Basic Permit and Trade Practice Division, Alcohol Tax Unit, Bureau of Internal Revenue. Author, The Scope of Federal Power Over Alcoholic Beverages Since the 2Ist Amendment (1940) 8 Geo. WaSH. L. Rev. 819 and 875.

${ }^{I}$ Nat. Comm. on Law Obs. and Enf., Report on the Enforcement of the Prohibition Laws of the United States (Wickersham Report), H. Doc. No. 722, 71st Cong., 3d Sess. (I93I) 6, 7.

${ }^{2}$ Fosdick and Scott, Toward Liquor Control (1933) 43, 44.

${ }^{3}$ The Circuit Court of Multnomah County, Oregon, in upholding regulations requiring price posting, said in Alberts Products Co., Inc., v. Oregon Liquor Control Comm. (May 13, 1936): "The Act states in its preamble one of its purposes is to prevent the recurrence of abuses associated with saloons or resorts for consumption of alcoholic beverages.

"Now, it is a matter of general knowledge that in pre-prohibition days, one of the great abuses connected with the liquor traffic was the control exercised by brewers over saloons, and to prevent that control wholesalers and manufacturers are prohibited from rendering any financial assistance to the retail dealers in beer.

"Section I2, by requiring wholesalers to file schedules of prices and to adhere to them, it seems to me, is a reasonable measure to prevent the giving of financial assistance which would tend to bring a retailer within the control of the wholesaler." 
avoid the evils of the pre-Prohibition tied-house. It happened that Repeal was coincident with the wave of desire for reform in competitive practices in industry generally, the movement being translated into New Deal legislation such as the National Industrial Recovery Act. ${ }^{4}$ The concept of fair competition, stressed in the industrial codes generally, contemplated the elimination of the rendering of secret discounts, rebates, and other special concessions to favored trade buyers. ${ }^{5}$ It is quite natural that those who were interested in avoiding the recurrence of the tied-house situation should look to the National Industrial Recovery Act as a vehicle for accomplishing the elimination of the devices formerly employed by brewers and distillers in gaining control of retail establishments. Those devices were in many respects identical with the practices which the codes under the National Industrial Recovery Act purported to eliminate in other industries.

Expediency also made it desirable to employ the codes as the vehicle for postRepeal regulation in the liquor industry, for Repeal had come so quickly that Congress had no time to consider regulation by legislation. The existing machinery of the National Industrial Recovery Act furnished an opportunity to provide immediate regulation and so avoid a period of confusion. Repeal became effective on December 5, 1933. By December 27th the last code of fair competition for the alcoholic beverage industry had been approved, some of them having been promulgated in anticipation of Repeal. They were to serve as a pattern for subsequent state and federal legislation $^{6}$ designed to prevent the return of the tied-house and to promote fair competition by prohibiting various forms of inducement.

\section{Prohibited Practices}

All of the codes in the alcoholic beverage field ${ }^{7}$ contained prohibitions against agreements between vendors and retail buyers, under which the retailers were bound to sell only the products of a particular member of the industry. A similar provision was incorporated in Section 5 (a) of the Federal Alcohol Administration Act. ${ }^{8}$ The prohibition in the act is more stringent than the code provisions in that it prohibits

48 Stat. 195 (1933).

The same policy underlies the Robinson-Patman ACt. 49 Stat. 1526 (I936), I5 U. S. C. \$13.

- The Federat Alcohol Administration Act, 49 Stat. 977 (1935) 27 U. S. C. \$201 (1938), passed as a substitute for regulation of the industry by codes following the invalidation of the N. I. R. A.

${ }^{7}$ Codes of fair competition for the alcoholic beverage wholesale industry, the brewing industry, the distilled spirits industry, the distilled spirits rectifying industry, the alcoholic beverages importing industry, and the wine industry.

${ }^{8}$ The section provides: "It shall be unlawful for any person engaged in business as a distiller, brewer, rectifier, blender, or other producer, or as an importer or wholesaler, of distilled spirits, winc, or malt beverages, or as a bottler, or warehouseman and bottler, of distilled spirits, directly or indirectly or through an affiliate:

"(a) Exclusive outlet: To require, by agreement or otherwise, that any retailer engaged in the salc of distilled spirits, wine, or malt beverages, purchase any such products from such person to the exclusion in whole or in part of distilled spirits, wine, or malt beverages sold or offered for sale by other persons in interstate or foreign commerce, if such requirement is made in the coursc of interstate or forcign commerce, or if such person engages in such practice to such an extent as substantially to restrain or prevent transactions in interstate or foreign commerce in any such products, or if the direct effect of such requirement is to prevent, deter, hinder, or restrict other persons from selling or offering for sale any such products to such retailer in interstate or foreign commerce." 
agreements which require a retailer to purchase products from the vendor to the exclusion, in whole or in part, of the products of competitors, subject, of course, to the jurisdictional requirements. Provisions aiming at the same practice appear in the laws of Alabama, Arizona, Arkansas, Georgia, Idaho, Illinois, Kentucky, Maryland, Minnesota, Missouri, New Jersey, New Mexico, New York, Ohio, Texas, Utah, and Washington. In a number of these states the prohibitions relate to beer only. Such restrictive contracts are not only prohibited but are specifically declared void and unenforceable in a number of the state statutes.

Closely related to the prohibitions of Section 5(a) are those of Section 5(b) (7) which prohibit the inducement of the retailer "by requiring the retailer to take and dispose of a certain quota of any of such products." Somewhat similar provisions are contained in the laws or regulations of Alabama, Arizona, Kentucky, Minnesota, New Mexico, Texas, and Utah.

The codes, except that of the importing industry, contained prohibitions against the holding of an interest in retail establishments selling alcoholic beverages for consumption on the premises. The practice is prohibited by Section $5(\mathrm{~b})(\mathrm{I})$ and Section 5(b) (2) of the Federal Alcohol Administration Act. ${ }^{9}$ It should be noted that the act went further than the codes, making no distinction between "on" and "off premises" retail establishments. Because the various practices referred to in Section 5(b) are prohibited only if they have the effect of inducing the retailer to purchase the products of the vendor to the exclusion in whole or in part of competing products, complete ownership of a retail establishment would not involve a violation as the inducement feature could not be present, while partial ownership might result in a violation.

The states quite generally adopted more direct and effective prohibitions against the ownership and control of retail establishments. The practice has been the subject of regulation in the following jurisdictions-Alabama, Arizona, Arkansas, California, Colorado, Connecticut, Delaware, Florida, Georgia, Idaho, Illinois, Indiana, Iowa, Kansas (3.2 beer only), Kentucky, Maryland, Massachusetts, Michigan, Minnesota, Mississippi, Missouri, Montana, Nebraska, New Hampshire, New Jersey, New Mexico, New York, North Dakota, Ohio, Oregon, Pennsylvania, Rhode Island, South Dakota, Tennessee, Texas, Utah, Vermont, Virginia, Washington, West Virginia, Wisconsin, Wyoming, and the District of Columbia.

Some of the states have adopted the code distinction between retailers selling alco-

\footnotetext{
- These subsections, under $\$ 5(b)$ entitled "Tied House," make it unlawful for the persons enumerated in II of note 8 supra: "To induce through any of the following means, any retailer, engaged in the sale of distilled spirits, wine, or malt beverages, to purchase any such products from such person to the exclusion in whole or in part of distilled spirits, wine, or malt beverages sold or offered for sale by other persons in interstate or foreign commerce, if such inducement is made in the course of interstate or foreign commerce, or if such person engages in the practice of using such means, or any of them, to such an extent as substantially to restrain or prevent transactions in interstate or foreign commerce in any such products, or if the direct effect of such inducement is to prevent, deter, hinder, or restrict other persons from selling or offering for sale any such products to such retailer in interstate or foreign commerce: ( 1 ) By acquiring or holding (after the expiration of any existing license) any interest in any license with respect to the premises of the retailer; or (2) by acquiring any interest in real or personal property owned, occupied, or used by the retailer in the conduct of his business."
} 
holic beverages for consumption on the premises and package stores, the prohibitions applying only to the on-premises establishments. Many of the state statutes not only prohibit an interest in retail establishments but also prohibit a holder of one class of permit from holding an interest in the business conducted under any other class of permit. Such laws, for example, would prohibit a distiller from owning an interest in a wholesale establishment.

In the matter of the furnishing of things of value to retailers, the provisions of the codes, the federal statute and the state laws vary extensively in detail but are similar in principle. They reveal that the legislatures and the administrative agencies have found it difficult to draw a dividing line between articles which might be furnished without serious danger of creating a tied-house condition and those which are likely to create a tied-house condition. The difficulty is accentuated by the fact that it is frequently impossible to ascertain when a certain concession is merely a price reduction and when it is the giving of money or something of value. The latter aspects will be discussed later in connection with prices.

The code provisions relating to malt beverages dealt more strictly with the furnishing of things of value than did those relating to distilled spirits and wine. They prohibited the furnishing, giving, or lending of "any money or other thing of value" to on-premises retail establishments, the furnishing, giving, lending, or renting of equipment, fixtures, or supplies to on-premises retail establishments, the furnishing of inside or outside signs costing more than $\$ 100$ in any one calendar year to onpremises retailers, the offering of any prize, premium, gift, or other similar inducements to trade or consumer buyers and the payment of any allowances or rebates, concessions or discounts in the form of money or otherwise not conforming with the prices and terms of sale as posted by the producer or manufacturer.

In the Federal Alcohol Administration Act, Congress made no distinction between the things which may be furnished by producers dealing in malt beverages and those dealing in other types of alcoholic beverages nor did it make any distinction between on-premises and off-premises retail establishments. Section $5(b)(3)$ prohibits the inducement of a retailer for the purposes and under the conditions stated by "furnishing, giving, renting, lending, or selling to the retailer, any equipment, fixtures, signs, supplies, money, services, or other thing of value, subject to such exceptions as the Administrator shall by regulation prescribe, having due regard for public health, the quantity and value of articles involved, established trade customs not contrary to the public interest and the purposes of this subsection."

The exceptions promulgated by the Administrator and contained in Regulations, No. 6, permit the furnishing of tapping accessories, signs for inside use, provided the cost does not exceed more than \$Io at any one time, carbonic acid gas or ice, coil cleaning services, a limited advertising service mentioning a retailer's name in an inconspicuous manner, consumer advertising specialties, and retailer advertising specialties, which are primarily valuable to the retailer as point of sale advertising media, samples not to exceed one pint to a retailer who has not previously purchased 
the particular product, newspaper cuts and, in the case of persons engaged in other lines of business, general merchandise such as groceries and drugs, provided they are not sold in combination with alcoholic beverages.

Louisiana, Nevada, North Carolina, North Dakota, Oklahoma, and Vermont are the only states which have not adopted some prohibitions similar to those of Section 5(b) (3) and Regulations, No. 6. The state prohibitions, however, vary materially as to the extent of allowable donations. With regard to signs, for example, some states permit indoor or outdoor signs up to $\$ 100$ in value; others prohibit indoor and outdoor signs completely. Others follow the \$ro limitation of the federal statute, while still others limit the signs by area. Indiana, which has spelled out in great detail the things of value which may not be furnished, prohibits signs if in plain view of a passerby and prohibits window displays and prohibits brand signs which are "so elaborate as to constitute interior decorations or which are so costly as to indicate subsidy."10 Kentucky permits the furnishing of exterior brand signs costing $\$ 150$ to retailers in cities of the first and second class. ${ }^{11}$ In Maryland the Criminal Court of Baltimore on December 8, I939 held in State v. Harrison ${ }^{\mathbf{1 2}}$ that where the purpose of the sign is to advertise the business of the wholesaler generally and not the business of the retailer, Section 28 , Article $2 \mathrm{~B}$ of the General Laws is not violated. The section makes it a violation "to furnish any sign ... . in value in excess of Five Dollars. ..." The case involved the furnishing of a whisky sign to a retailer of beer and wine.

On May 20, 1937, the Massachusetts Alcoholic Beverage Control Commission ordered brewers and distillers "to cease loaning signs to retail licensees," stating: "One of the basic principles underlying the provisions of the liquor control act is that there shall be a complete disassociation between brewers and retail licensees and distillers and retail licensees ... facts disclosed at the conference show that brewers have loaned signs to retail licensees of value well in excess of a quarter of a million dollars. Such a situation, if permitted to continue, will lead to the so-called 'tiedhouse' control of the entire industry." The release was issued on the basis of Regulations, No. I8, which provides in part that "No licensee shall offer any prize, premium, gift, or other similar inducement except advertising novelties of nominal value to aid or promote the sale of alcoholic beverages." On June 16 , 1937 , the Commission revised its opinion and held that the regulation did not apply to the lending of signs advertising the products of the manufacturer. On March 17, r938 the Commission held that the making of cash contributions to a retailer for a sign was "in direct violation of the regulations. ..." It stated: "there is a vast difference between a manufacturer or wholesaler and importer making an outright contribution of any sum of money to help defray the cost of a sign and the practice of manufacturers and wholesalers and importers of loaning signs which advertise their products as well as the retailers' establishments."

\footnotetext{
${ }^{10}$ Regs. I, $\$ 5$ (b) (June 2I, 1938). ${ }^{11}$ Reg. LCB-2, (July 20, x938).

${ }^{12}$ Abstract of oral opinion, Balt. Daily Record, January 19, 1940.
} 
In those cases in which the statute prohibits the furnishing of exterior signs to retail establishments, the question arises as to when a particular sign on the side wall or roof of a building is merely a billboard of value to the advertiser or a sign calling attention to the retail establishment. The divergent treatment of the sign problem and the variety of interpretations of similar statutes and regulations indicate the need for cooperation between the states.

The extent to which retailer and consumer advertising specialties may be furnished to retailers in the various states is also without uniformity. The Idaho Beer Law $^{13}$ makes it unlawful for a brewer or a wholesaler, directly or indirectly, to aid or assist any licensed retailer by gifts, loans of money, property of any description or services of any nature. This Section was interpreted on March 5, r940 in a notice to brewers and beer wholesalers to prohibit the furnishing of "novelties of all kinds, as well as beer trays, ash trays, menus, etc." Some states require all such novelties to be approved by the administrative agency involved, merely prohibiting the furnishing of such novelties as are not of nominal value, while others have no restrictions whatsoever. Others prohibit the furnishing of any articles which tend to influence purchases.

The codes contained prohibitions against paying, crediting, or otherwise compensating a trade buyer for an advertising, display, or distribution service. This prohibition was adopted as Section 5(b) (4) of the Federal Alcohol Administration Act ${ }^{14}$ with the modification that it applied only to payments to retailers for advertising, display, or distribution services furnished to retailers and did not apply to such payments made to wholesalers. Prohibitions against this practice are contained in the laws or regulations of Alabama, Arizona, California, Connecticut, Georgia, Kentucky, Michigan, Minnesota, Missouri, New Mexico, Oregon, Pennsylvania, Texas, and Utah. In some of these states the prohibition applies only to on-premises retail establishments. General language in the statutes and regulations of other states appears to be broad enough to cover payments for advertising, display, or distribution services.

Section 5(b) (5) of the Act, which prohibits the inducement of a retailer "by guaranteeing any loan or the re-payment of any financial obligation of the retailer" had its origin in the code provisions relating to malt beverages. They applied only to on-premises retailers, while the statute applies to both on-premises and off-premises retailers. Provisions which would accomplish approximately the same result are present in many of the state statutes, among them Alabama, Arizona, California, Colorado, Kentucky, Maine, Minnesota, Texas, Utah, Washington, and Wyoming. A number of other states have provisions prohibiting the rendering of financial assistance which would be broad enough to cover cases falling within Section $5(b)(5)$ of the federal statute.

\footnotetext{
${ }^{13}$ Idaho Laws 1935 , c. 132, $\$ 6(a)$, as amended by Laws I939, c. 242.

2* The subsection reads "(4) by paying or crediting the retailer for any advertising, display, or distribution service."
} 
The codes provided for the posting of prices and terms of sales. There was, however, no specific regulation of the credit which might be extended by the manufacturer, importer, or wholesaler to retailers. Apparently recognizing that the extension of credit was an effective means of tying a retailer, Congress enacted Section 5 (b) (6) which specifically prohibits the inducement of a retailer "by extending to the retailer credit for a period in excess of the credit period usual and customary to the industry for the particular class of transactions, as ascertained by the Administrator and prescribed by regulations by him." In Regulations No. 8, the Administrator found the usual and customary credit period to be thirty days. State credit regulations vary materially.

There are inherent difficulties in the enforcement of any credit regulations which do not restrict sales to retailers who are in default. The problem has been met by many of the states by requiring vendors to report to the administrative agency involved the names of all retailers who have failed to pay their accounts in full at the termination of the credit period specified. The regulations and statutes of some states prohibit the creditor from selling to a retailer who is indebted to him for more than the period specified but permit other wholesalers to sell to the delinquent retailer. Still others go further and make it a violation for any licensee to sell to a retailer who is indebted to any licensee. The periods vary from ninety days to immediate payment. $^{15}$

${ }^{15}$ Alabama requires sales for cash only. Arizona permits no credit. Arkansas requires all sales to be made for cash and abolishes a right of action for merchandise sold on credit. California authorizes the Board to fix the terms of credit. Connecticut has a 30 day credit limitation and makes it a violation for anyone to sell to a delinquent retailer with knowledge of such delinquency. Delaware requires retailers to pay their accounts in full by noon of the Saturday of the week following delivery. Florida permits the extension of credit in the "usual course of trade" in regard to liquor but requires cash transactions in regard to beer. In Georgia malt beverages may be sold for cash only, while 30 day credit is allowed in the case of distilled spirits, the State requiring reports by wholesalers as to the names of delinquent retailers. No wholesalers can do business with delinquent retailers. Idaho requires that beer sales be made for cash only. Illinois has a go day credit period. In Indiana all beer sales must be made for cash, but 15 days credit is allowed for liquor. Wholesalers may not sell to delinquents. In Kansas 3.2 beer may not be sold on credit. Maine requires sales to be for cash only. In April, 1938, Maryland held that the granting of credit for more than 30 days was considered a gift or gratuity within the meaning of the statute but made no provision prohibiting wholesalers from selling to delinquent retailers. On December r, 1938, the State found that the system did not work and required that all sales to delinquents be for cash only. Massachusetts allows 90 days. Michigan requires that all malt beverages be sold for cash. Minnesota has a 30 day provision. Missouri requires payment within 30 days of the invoice date and denies renewal of retailers licenses if their accounts are not fully paid. Nebraska has a go day provision, while New Hampshire requires payment within Io days. The New Jersey Alcoholic Beverage Law gives the Commissioner the power to regulate "sales on credit." In New Mexico a wholesaler must sell for cash to a retailer who is indebted to him for more than 30 days. The extension of credit is regarded as a "service." New York requires payment of all accounts by the tenth of the month following delivery. The state mails a list of all delinquents to the trade, who may sell only for cash until the name is removed from the next monthly list. In Ohio beer sales must be for cash and a right of action to collect is abolished if sales were made on credit. Oregon requires all sales of wine and malt beverages to be for cash and can order the violating wholesaler to discontinue all sales to the delinquent retailer for a period deemed proper by the commission. In Pennsylvania, malt beverages may be sold for cash only. Rhode Island, which fixes a 15 percent mark-up for the wholesaler and provides for quantity discounts, provides that the discounts shall not be allowed unless the account is paid within 30 days. South Carolina requires payment within I5 days and all delinquents must be reported to Tax Commission, which circularizes their names. All wholesalers are forbidden to make further sales to such retailers. Lists are issued weekly. 
Closely related to credit regulation are the prohibitions against the sale of merchandise on consignment or with the privilege of return. In both types of transactions the retailer receives financial assistance likely to obligate him to his benefactor. Section 5(d) of the Federal Alcohol Administration Act, ${ }^{16}$ which had its origin in the codes, prohibits such transactions even though they do not "induce" within the meaning of Sections $5(\mathrm{~b})$, and (c). Consignment sales to wholesalers as well as such sales to retailers are prohibited. The recipient of the merchandise is also guilty of a violation. A comparatively small number of states have adopted specific prohibitions against selling on consignment. ${ }^{17}$ Such a prohibition would not appear to be necessary where credit is prohibited. Credit limitations would not, however, operate to restrict the sale of merchandise with the privilege of return.

All of the codes of fair competition in the alcoholic beverage industries and those of many other industries contained prohibitions against commercial bribery with slight variations in language. Section $5(c)$ of the Federal Alcohol Administration Act $^{18}$ prohibits the inducement of a retailer or a wholesaler by commercial bribery in the conventional sense, i.e., the giving of remuneration to employees without the knowledge of the employer, and also by offering or giving a bonus, premium, or compensation to officers, employees, or representatives of the trade buyer with the

Tennessee requires payment in ten days and sales may be made to delinquents only for cash. The Attorney General of Texas has ruled that the Texas Liquor Control Board does not have power to restrict credit terms. Vermont prohibits the sale of wine or beer on credit. Virginia requires that beer sales be made for cash. Beer and liquor sales in Washington must be for cash. The Board has the power to withhold licenses from wholesalers who have not collected their accounts. West Virginia requires bect sales to be for cash and abolishes a right of action for sales on credit. In Washington, the Legislature by a Joint Resolution attempted to empower the State Treasurer to set up credit limitations but the Attorncy General held that this "resolution" did not accomplish its purpose as it had not been signed by the Governor and was not a law. In Wyoming sales may be made for cash only.

${ }^{10}$ The section reads: "(d) Consignment sales: To sell, offer for sale, or contract to sell to any trade buyer engaged in the sale of distilled spirits, wine, or malt beverages, or for any such trade buyer to purchase, offer to purchase, or contract to purchase, any such products on consignment or under conditional sale or with the privilege of return or on any basis otherwise than a bona fide sale, or where any part of such transaction involves, directly or indirectly, the acquisition by such person from the trade buyer or his agreement to acquire from the trade buyer other distilled spirits, wine, or malt beveragesif such sale, purchase, offer, or contract is made in the course of interstate or foreign commerce, or if such person or trade buyer engages in such practice to such an extent as substantially to restrain or prevent transactions in interstate or foreign commerce in any such products, or if the direct effect of such sale, purchase, offer, or contract is to prevent, deter, hinder, or restrict other persons from selling or offering for sale any such products to such trade buyer in interstate or foreign commerce: Providcd, That this subsection shall not apply to transactions involving solely the bona fide return of merchandise for ordinary and usual commercial reasons arising after the merchandise has been sold."

${ }^{17}$ Ark., Cal., Del., Fla., Ga., Mass., Minn., N. J., N. M., Tex., Utah.

${ }^{18}$ The section reads: "(c) Commercial bribery: To induce through any of the following means, any trade buyer engaged in the sale of distilled spirits, wine, or malt beverages, to purchase any such products from such person to the exclusion in whole or in part of distilled spirits, wine, or malt beverages sold or offered for sale by other persons in interstate or forcign commerce, if such inducement is made in the course of interstate or foreign commerce, or if such person engages in the practice of using such means, or any of them, to such an extent as substantially to restrain or prevent transactions in interstate or forcign commerce in any such products, or if the direct effect of such inducement is to prevent, deter, hinder, or restrict other persons from selling or offering for sale any such products to such trade buycr in interstate or foreign commerce: (1) By commercial bribery; or (2) by offering or giving any bonus, premium, or compensation to any officer, or employee, or representative of the trade buyer." 
knowledge of the employer. ${ }^{19}$ The following states contain prohibitions aimed at the practice-Alabama, Arizona, Arkansas, California, Connecticut, Delaware, Georgia, Idaho, Illinois, Indiana, Kentucky, Maine, Michigan, Minnesota, New Mexico, Oregon, Pennsylvania, Texas, Utah, and Washington. In some of the states commercial bribery is not spelled out as a separate offense but the general prohibition against the furnishing of things of value to retailers includes prohibitions against furnishing things of value to their employees.

In nearly all of the trade practice provisions there is an important distinction to be noted between the treatment of the problem by the state and federal governments. Because the states have immediate control over the operations of the retailer, the laws and regulations dealing with illegal transactions between retailers and their vendors quite generally make such transactions violations by both parties. With the exception of violations under Section 5 (d) of the federal statute, retailers are not subject to its trade practice provisions.

\section{JURISDICTION}

The jurisdictional provisions of Sections 5(a), "Exclusive Outlet," 5(b), "Tied House," and $5(\mathrm{c})$, "Commercial Bribery," are involved and redundant. In each of them practices are proscribed only if they cause the retailer or trade buyer, as the case may be, to purchase the products of the person engaging in the practices "to the exclusion in whole or in part of distilled spirits, wine, or malt beverages sold or offered for sale by other persons in interstate or foreign commerce." This fundamental element, essential to the finding of a violation, is further qualified in each of the sections in question by a requirement that one of three alternative jurisdictional conditions be satisfied: (I) If the requirement or transaction is in interstate or foreign commerce; (2) if the practice is engaged in "to such an extent as substantially to restrain or prevent transactions in interstate or foreign commerce"; or (3) "if the direct effect" of such requirement (or inducement) "is to prevent, deter, hinder, or restrict other persons from selling or offering for sale any such products to such retailer" (or trade buyer) "in interstate or foreign commerce."

It would seem that if the first alternative were present the transaction would be within the field of federal power and Congress would not have had to rely upon the

${ }^{10}$ The distinction between $\S 5(\mathrm{c})(\mathrm{r})$ and $5(\mathrm{c})(2)$ was recognized in American Distilling Co. v. Wisconsin Liquor Co., I04 F. (2d) 582 (C. C. A. 7th, 1939) in which the defendant contended that its contract of purchase from the plaintiff was illegal and unenforceable because among other things, plaintiff had given money and gratuities to salesmen of the defendant in violation of the Federal Alcohol Administration Act. The Court said at 585: "Section 205 (c) 27 U. S. C. A. [Section 5(c) of the Act] denounces two practices, ( $I$ ) commercial bribery, and (2) the offering or giving of any bonus, premium, or compensation to any officer, or employee or representative of the trade buyer. The Act does not define 'commercial bribery' and its intended meaning must be sought in its normal meaning and usage. . . .

"The vice of conduct labeled 'commercial bribery' as related to unfair trade practices, is the advantage which one competitor secures over his fellow competitors by his secret and corrupt dealing with employees or agents of prospective purchasers." The court held that as the gifts were not made secretly they did not constitute "commercial bribery." It said, however, "But when Congress adds to the practice of 'commercial bribery' the 'offering or giving of any bonus, premium or compensation,' we see no justification for our imposing qualifying adjectives. ..." As the case was decided on other grounds, the pronouncement on the distinction between Section $5(\mathrm{c})(\mathrm{I})$ and $5(\mathrm{c})(2)$ is dictum but the distinction appears sound. 
requirement that the practice exclude "in whole or in part" products "sold or offered for sale in interstate or foreign commerce." It would seem that if the second and third alternatives are present the fundamental element would necessarily be present. The Administrator of the former Federal Alcohol Administration on three occasions recommended to Congress legislation which would have cured the redundancy. ${ }^{20}$ A bill for the purpose was introduced in 1939 but was never passed. ${ }^{21}$

Federal jurisdiction over practices in the malt beverage industry is materially curtailed by the provisions of the next to the last paragraph of Section 5 of the act. ${ }^{22}$ The statute applies, in the case of malt beverages, only to transactions in interstate commerce and then only if the laws of the state where the retailer is located contain prohibitions similar to those of the federal statute.

The alcoholic beverage industry is organized on a national and highly competitive scale, making it an appropriate subject for federal regulation. In 1938 four large distilling companies doing a national business produced $64 \%$ of the total whiskey production. They held $54 \%$ of all stocks of whiskey in bonded warehouses and held $78 \%$ of the total stocks of whiskey four years old and over remaining in bonded warehouses. ${ }^{23}$

Sales are made through wholesalers, whose policies are, for the most part, dictated by producers. "Missionary men" of the manufacturer attend meetings of the salesmen of the wholesaler and call on the retail trade independently or with the wholesaler's salesmen, in some cases taking orders for the wholesaler and offering concessions and inducements directly to the retail trade. Special deals offered by the wholesaler are generally ordered by the manufacturer who demands that wholesalers holding franchises under him comply strictly with his sales policies.

The keenest competition is between the nationally advertised brands of the large producers who cover the United States with vast sales and promotional organizations. There is also competition from the smaller producers, many of whom place on the market private brands bearing the name of a wholesaler or retailer. They compete with the nationally advertised brands on price but they cannot displace nationally advertised products, which every retailer must carry to satisfy his trade. Because of the nature of the organization of the industry and the nature of the competition, there is a very real effect on interstate commerce when a producer, to strengthen his position in a particular market, engages in the practices proscribed in the act.

While it might seem that a fifty cent gift by missionary men to a bartender might not have a direct or substantial effect on interstate commerce, the effect is substantial and immediate when such gifts are given as a matter of sales policy throughout a

${ }^{20}$ ANN. REPS. (1937, 1938, 1939).

${ }^{21}$ H. R. 6219, 76th Cong., 2nd Sess. (1939).

${ }^{22}$ It reads: "In the case of malt beverages, the provisions of subsections (a), (b), (c), and (d) shall apply to transactions between a retailer or trade buyer in any State and a brewer, importer, or wholcsalcr of malt beverages outside such State only to the extent that the law of such State imposes similar requirements with respect to similar transactions between a retailer or trade buyer in such State and a brewer, importer, or wholesaler of malt beverages in such State, as the case may be."

${ }^{23}$ Hearings before the Temporary National Economic Committee of Congress, 76th Cong., 2nd Scss. (1939) Exhibits 400, 401, 402. 
given territory. The competition for the friendship and good will of retailers and their employees is intense and producers who decide to make an impression on a particular market spend large sums to accomplish the result.

While most of the states attempt to control the practices of out-of-state producers through prohibitions against the receipt of inducements by retailers and through their control of wholesalers within their borders and in some cases through the licensing of missionary men, the states have no effective jurisdiction and no opportunity to investigate the operations of the shipper responsible for promotion policies. While in some cases the states have been able to bar products of certain producers from their borders for limited periods because of violations by their agents, divergent enforcement measures by individual states are an ineffective curb to illegal promotional campaigns carried on on a sectional or national basis. The problem is primarily a federal one.

In the beer field there is little opportunity for effective federal enforcement because of the limitations on jurisdiction imposed by the next to the last paragraph of Section 5. Probably the most serious practices in the beer field are those involving the furnishing of bars and dispensing equipment to retailers indirectly through closely associated equipment houses.

Producers and wholesalers of distilled spirits and wine have sought to gain the favor of retailers principally through the furnishing of less expensive articles of equipment, signs and devices which fall more nearly within the category of retailer advertising specialties. The problem in this field is primarily one of determining where the dividing line is to be drawn.

\section{Grfts of Money and Price Concessions}

A much more fundamental difficulty exists in connection with the very broad language employed in the federal statute and in many of the state laws. Quite generally, they contain provisions against the furnishing of money or other things of value. This prohibition is so closely related to price that the line of demarcation, in many cases, is difficult to draw. In the codes the prohibitions against the giving of "rebates, refunds, concessions, or discounts, whether in the form of money or otherwise" were contained in the provisions relating to the posting of prices. The codes made no effort to fix prices but they required that an industry member declare his prices and live up to them. The Federal Alcohol Administration Act contains the broad prohibition against the giving of "money ... or other thing of value" but Congress discarded the price-posting provisions.

The same situation exists in many of the states. In such jurisdictions a basis for distinguishing price concessions from gifts of money is sometimes difficult to find. The case in which a vendor hands a retailer a $\$ 2.00$ bill to induce him to purchase a $\$ 20.00$ case of liquor would seem to involve a gift of money to the retailer as an inducement. If, instead of giving the retailer money, the vendor gives him a $\$ 2.00$ bottle of merchandise and invoices the case at the usual price, the extra bottle being 
represented as a gift, it might be argued that something of value was given to the retailer. ${ }^{24}$ Does the fact that the extra merchandise is not represented as a gift change the character of the transaction? A few distillers have attempted to evade the prohibitions of the various jurisdictions on this point by packaging their liquor in cases containing thirteen or fourteen bottles instead of the conventional twelve bottle case.

The producer, in formulating deals for limited periods in order to strengthen his position in a given market, would much prefer to offer free merchandise to the trade, while maintaining his unit case price, than to reduce the case price for a limited period. This latter method, it may be observed, would clearly be permissible under the federal statute and many of the state statutes. The producer's reasons for the preference appear to be twofold. First, the retailer, like the gullible consumer, likes to feel that he is getting something for nothing. The second and probably the most important reason is that the producer desires to maintain his case price. A price reduction, though announced as temporary, leads the trade to expect a permanently lower price.

\footnotetext{
24 The New York courts have taken a different view. The Alcoholic Beverage Control Law, \$101(1-c), makes it unlawful for a manufacturer or wholesaler "to make any gift or render any service ... . which in the judgment of the liquor authority may tend to influence such licensee to purchase the product of such manufacturer or wholesaler." The evidence in Pennsylvania Whiskey Distributing Corp. v. Bruckman, 256 App. Div. 781, II N. Y. S. (2d) 718, 720 (1939), established that the manufacturer had sold ten barrels of whiskey to retailers, the salesman agreeing "to supply 'free' one extra barrel." The State Liquor Authority alleged that this was a gift within the meaning of the statute. The Appellate Division said, "A 'gift' is a voluntary transfer of property without any consideration or compensation therefor (Gray v. Barton, 55 N. Y. 68; McKenzie v. Harrison, 120 N. Y. 260; Matter of Van Alstyne, 207 N. Y. 298). A sale is defined as any transfer of title or compensation or both for a consideration. (Matter of Sears, Roebuck \& Co. v. McGoldrick, 279 N. Y. 184 ). If, then, the additional barrel of whiskcy was furnished in consideration of the purchase of ten other barrels, how can it be said to constitute a 'gift' made without consideration. In theory, the arrangement consisted of a collateral agreement by which the petitioner undertook to supply the additional barrel of whiskey in consideration of the purchase of ten other barrels. (Mitchell v. Lath, 247 N. Y. 377). Considered more realistically, it was the sale of cleven barrels for the price of ten (Compare, People v. Miller, $27 x$ N. Y. 44; Pcople ex rel. Ellison v. Lavia, $x_{79}$ N. Y. 164,168$)$. Although it is true, no doubt, that an additional barrel would, in the language of the statute, 'tend to influence such licensee to purchase the product of such manufacturer or wholesaler,' as would a reduction in the purchase price, that is not an offense under the statute unless it is accomplished through the medium of a 'gift.' The practice at which the statute appears to have been directed was the furnishing of free liquor, in large or small quantities, in order to influence the patronage of retailers. It was not intended to regulate the price at which liquor might be sold by prohibiting a reduction in price resulting from a contract to deliver a large quantity of liquor." The decision was upheld by the Court of Appeals, 282 N. Y. 665,26 N. E. (2d) 804 (1940).

If the theory advanced by the court that the free merchandise could not be a gift because it was consideration for the purchase of the ten barrels is sound, a gold watch furnished to each purchaser of a specified quantity would not be a gift. It would seem that the decisions have nullified to a large extent the intention of the legislature. The statute proscribes only those gifts which influence sales. Under the language of the decision articles supplied free with whisky would cease to be "gifts" because they had the very result essential to the finding of a violation. The only transaction covered by the act as interpreted would be where an article or money was furnished free and it later resulted in a purchase as an entirely separate transaction. So interpreted, the statute does not cover the prevalent practices at which it was aimed. A broader interpretation of "gift" in this particular statute would appear to be sustainable in view of the provision that they must influence sales and in view of the fact that such influenced sales would in almost all cases constitute consideration.

In American Distilling Co. v. Wisconsin Liquor Co., supra note 19 , it was stated, at 585 , that a free case of liquor was in fact a quantity discount and not a gift. The statement was dictum. See also 123 A. L. R. 748 (1939).
} 
Where the state laws require the posting of prices to retailers, as was the case in the codes, the administrative agency can take the position that any concessions not conforming to the declared prices would constitute the giving of something of value. Legislation requiring all terms of sale to appear on the invoice and prohibiting all concessions which do not appear offers an opportunity for an agency to take the position that all such secret concessions involve the giving of money or something of value. Whether a concession is a gift or a price reduction makes little real difference, yet because of the language of many of the statutes the distinction must be drawn. ${ }^{25}$

The practice of producers of offering free deals, discounts, and secret rebates in license states to strengthen a brand was of serious concern to the monopoly states, which paid list prices. The problem became so acute that in 1937 the Monopoly Group of the National Conference of State Liquor Administrators decided to purchase only under a warranty by the vendor that they were receiving "the lowest base price." The following year when the monopoly states organized the National Alcoholic Beverage Control Association it agreed upon a similar warranty for "the lowest net base price."26

\section{Price Stabilization}

\section{(a) In General}

While many of the state so-called fair-trade acts would be broad enough to enable a producer to regulate the price at which the wholesaler sold to the retailer, they are not generally used for this purpose. Their primary function is to establish a uniform resale price to the consumer. The state fair-trade acts generally provide that a contract relating to the sale or resale of a commodity bearing a trade-mark or brand name which is in fair and open competition with commodities of the same general class produced by others, shall not be deemed in violation of the anti-trust or other laws of the state because they contain provisions requiring the purchaser to resell at or above a stated price or to obtain agreements from his vendors that they in turn

\footnotetext{
35 The Robinson-Patman Act, supra note 5, designed to prevent discrimination among buyers of the same class, has a direct bearing on the practice of giving free deals and secret rebates to retailers. The statute, which amended the Clayton Anti-Trust Act, and also contained separate distinct provisions, makes it unlawful in interstate commerce "to discriminate in price between different purchasers of commodities of like grade and quality." $\$ 2$ (d) makes it unlawful for any person engaged in commerce "to pay or contract for the payment of anything of value to or for the benefit of a customer . . . as compensation or in consideration for any services or facilities furnished by or through such customer in connection with ... the sale or offering for sale" of the products of the vendor "unless such payment or consideration is available on proportionately equal terms to all other customers competing in the distribution of such products or commodities." Sec. 2 (e) makes it unlawful to furnish discriminatory services or facilities to the purchaser.

While there are similarities between these provisions and those of the federal and state statutes prohibiting the furnishing of money, services, or things of value, such practices are prohibited by the Robinson-Patman Act only when they are not equally available to all persons of the same class, while most of the liquor control statutes prohibit such inducements even if they are available to all customers of the same class. The distinction between prices and gifts must therefore be drawn. It is probable that many violations of the liquor statutes on this subject also involve violations of the Robinson-Patman Act, as discrimination is frequently present. ${ }^{20} T$. N. E. C. Hearings, stipra note 23 , at 2574 .
} 
will resell at or above the stipulated price. ${ }^{27}$ Exceptions are provided for in the case of close-out sales, sales of damaged goods, and sales under court orders. By explicit terms horizontal agreements between producers, or between wholesalers, or between retailers are not under the protection of the statutes.

The acts generally contain a provision making it unfair competition for a person to sell at a price lower than the stipulated price, even though he is not a party to the contract, if he has knowledge of such a contract. Such sales are actionable at the suit of any person damaged. The provision requiring non-contracting parties to abide by resale prices fixed by contract was upheld by the Supreme Court in Old Dearborn Distributing Co. v. Seagram Distillers Corp. ${ }^{28}$ and McNeil v. Joseph Triner Corp..$^{20}$ The Court stated in the Seagram case that $\$ 2$ of the Illinois Act imposing an obligation on non-contracting dealers "does not deal with the restriction upon the sale of the commodity qua commodity, but with that restriction because the commodity is identified by the trade-mark, brand or name of the producer or owner. The essence of the statutory violation then consists not in the bare disposition of the commodity, but in the forbidden use of the trade-mark, brand or name in accomplishing such disposition. The primary aim of the law is to protect the property-namely, the good will - of the producer, which he still owns. The price restriction is adopted as an appropriate means to that perfectly legitimate end and not as an end itself."30

Fair-trade contracts are expressly legalized under fair-trade acts in 44 states. There are no such statutes in Delaware, the District of Columbia, Missouri, Texas, and Vermont. Such contracts are, however, legal in all jurisdictions except Missouri, Texas, and the District of Columbia. Obviously in Delaware and Vermont where the contracts are legal merely because there are no laws prohibiting them and not because of affirmative legislation, non-contracting dealers are not required to abide by established prices.

Prior to the passage of the Miller-Tydings Act ${ }^{31}$ as an amendment to the Sherman Anti-Trust Act, the Supreme Court held in Dr. Miles Medical Co. v. Park \& Sons $\mathrm{Co}^{32}$ that the Sherman Act prohibited vertical price maintenance agreements between producers and distributors as well as horizontal agreements. The Federal Trade Commission Act prohibiting "unfair methods of competition" was also construed to prohibit such agreements in interstate commerce. ${ }^{33}$ The Miller-Tydings Act amending Section I of the Sherman Anti-Trust Act provides "that nothing herein contained shall render illegal contracts or agreements prescribing minimum prices for resale of a commodity which bears, or the labels or container of which bears the trade-mark, brand, or name of the producer or distributor of such commodity and which is in free and open competition with commodities of the same general class produced or distributed by others, if contracts or agreements of that

\footnotetext{
${ }^{27}$ For a discussion of the various types of contracts see C. C. H. Trade Reg. Serv. 1577.

${ }^{28} 299$ U. S. 183 (1936).

29 Ibid.

${ }^{30} \mathrm{Id}$. at $\mathrm{r} 93$.

${ }^{31}$ 50 StaT. 693 (1937), 15 U. S. C. $\$$ r. $\quad{ }^{32} 220$ U. S. 373 (I9II).

${ }^{33}$ Fed. Trade Comm. v. Beech-Nut Packing Co., 257 U. S. 441 (I922).
} 
description are lawful as applied to intrastate transactions under any statute, law or public policy now or hereafter in effect in any state. ..." It is to be noted that the Miller-Tydings Act validates only such contracts or agreements and makes no reference to the statutory obligation imposed by the various states on non-contracting parties to maintain resale prices fixed in contracts between others.

As the liability imposed on a non-contracting party is purely statutory and as a state can have no jurisdiction beyond its borders, it has been suggested that the provisions of a state's fair-trade act relating to non-contracting dealers may not apply in general commodities to interstate sales. ${ }^{34}$ Whether or not this view is sustainable as to general commodities, it is probable that in the case of alcoholic beverages, because of the increased power of the states in regard to liquor under the Twenty-first Amendment, states could impose liability on non-contracting parties within the state though they bought in interstate commerce.

It is customary to negotiate fair-trade contracts with a large number of retailers in a given trading area. It would seem that if a single contract and notice are enough to place a fair-trade act into operation and impose obligations upon non-contracting parties within the state, as was held in Revlon Nail Enamel Corp. v. Charmley Drug Shop, ${ }^{35}$ all retailers but the original contracting retailer are bound by statute to sell at the resale price and therefore any agreement by them to do what they are already obliged to do would not constitute consideration for the contracts.

The question is academic as to intrastate sales for it would merely mean that suits against all but the first contracting price cutter would have to be brought under the statutory right of action rather than under contract. If, in the interstate situation, contracting parties only are obliged to sell at the established resale price, ${ }^{36}$ contracts subsequent to the first contract would be valid as the retailer would then be agreeing to do something which he was not obligated to do under state law and all suits against him would have to be on the contract theory.

\section{(b) Application in Alcoholic Beverage Field}

It has been seen that in the codes the provisions against the giving of money and other concessions were incorporated in price-posting provisions and were designed to make them effective. Similar implementing provisions against gifts and concessions are contained in many of the fair-trade price laws "for the purpose of preventing evasion of the resale price restrictions." ${ }^{37}$ A secondary effect of the fair-trade acts is, therefore, to support tied-house legislation in the liquor field. Similar support comes from the so-called unfair practice acts prohibiting sales below cost.

This was only one of the reasons, and perhaps a minor one, which led to the rapid adoption of price stabilization legislation in the industry. Vicious and frequent price wars among retailers, vigorous competition among manufacturers and wholesalers plus the growing power of organizations of retailers looking for stabilization and

\footnotetext{
${ }^{34}$ C. C. H. Trade Reg. Serv. $\$ 580.30$.

${ }^{30} 123$ N. J. Eq. 30I, 197 Atl. 661 (1938). ${ }^{30}$ Supra note 34.

${ }^{37}$ See Georgia Fair Trade Act, Laws I937, No. 100.
} 
greater profits, coupled with a realization by the states that in the field of liquor they were not subject to as many constitutional restrictions because of their increased powers under the Twenty-first Amendment, led to bold and drastic experiments in price control.

Price posting, regulation by private associations, mandatory resale price maintenance contracts, price fixing by the state, floors under prices and roofs over them, regulation of mark-ups, control of prices by administrative discretion, and elaborate combinations of these measures have been adopted. Because the experiments came at a time when neither the fair-trade law nor the constitutional law on liquor was settled, and because federal jurisdiction is affected by the laws of the individual states in both of these fields of law, there is uncertainty as to the validity of much of this legislation.

Eighteen states have independent price stabilization legislation written into the alcoholic beverage statutes. Where there is no such legislation relating specifically to liquor, that commodity is treated like any other under the conventional price stabilization acts. The most popular special price legislation in the alcoholic beverage field is that which prohibits the sale of alcoholic beverages in a state unless it is sold pursuant to fair-trade contracts. Arizona, Arkansas, California, Georgia, Indiana, Kentucky, Minnesota, New Mexico, Oregon, and South Carolina have such provisions. In some of the states contracts must be approved by administrative officers; in a number of them filing of a contract on a brand by one dealer excuses the others from filing; in others the contracts need not be filed, but the prices must be posted with the authorities. Publication is sometimes required in trade papers and in a number of states all parties affected must be notified individually. Some provide for maximum periods before prices can be changed. Some specifically include private labels while many of them follow the conventional pattern and make the fair-trade acts applicable only to merchandise in competition.

Arizona prohibits the sale of any distilled spirits or wine, including private brands, in the state, except pursuant to the fair-trade contract approved by the Superintendent of the Department of Liquor Licenses and Control..$^{38}$ Failure to sell at the fair-trade price is grounds for suspension or revocation. Written permission may be obtained for close-out sales at lower prices, but if denied, the wholesaler, owner, or producer is required to repurchase the merchandise from the retailer closing out his business. Arkansas has similar provisions. ${ }^{39}$ All wholesalers must be notified of prices, ${ }^{40}$ which do not become effective until ten days after filing with the Commissioner. ${ }^{41}$ A wholesaler must maintain stock on his shelves for ninety days before he can apply to post a lower price. ${ }^{42}$

California prohibits the sale of distilled spirits, including private brands, except pursuant to fair-trade contracts and requires filing of contracts with the State Board

\footnotetext{
${ }^{38}$ Reg. 4 (Jan. I, 1940).

${ }^{39}$ Reg. $2 x$ (Aug. 3I, 1938).

"1 Acts I939, No. $352, \$ 4$.
}

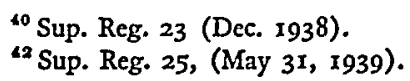


of Equalization, the publishing of prices in a trade journal and notification to licensees. ${ }^{43}$ The filing on a brand by one licensee excuses others from filing. Separate prices for northern and southern California are permitted. Close-outs below stipulated prices are permitted on application only after the merchandise has been in the state for six months.

The relationship between the prohibitions against giving things of value in the tied-house statutes and the fair-trade acts is illustrated by a quotation from the resolution of the California State Board of Equalization preceding the adoption of the regulation above referred to: "Whereas, producers and distributors of distilled spirits have resorted to price cutting, price discrimination, commercial bribery, gifts of free goods, and dumping in an effort to obtain an even greater volume of sales . . . now therefore . . . it being the further judgment of the Board that the following rule will tend to curb the evils complained of, the same is hereby adopted."

Georgia requires all distillers, rectifiers, importers, wholesalers, and retailers doing business in the state to enter into fair-trade agreements, which are "subject to the


sell liquor at quantity discounts ranging from $\mathrm{I} \%$ to $4 \%$ on quantities of from one to twenty-five or more cases. The right to collect this discount is forfeited if the accounts are not settled in fifteen days. ${ }^{45}$

Idaho requires all persons selling beer for resale to filo price schedules and to sell at the scheduled prices, but there is no specific provision for resale price maintenance in the alcoholic beverage field. ${ }^{46}$

In order to enforce the provisions in the Alcoholic Beverages Act ${ }^{47}$ prohibiting the furnishing of rebates, money, and other concessions, the Alcoholic Beverages Division of the State of Indiana, on April $4,1940,{ }^{48}$ called attention to the requirement that prices be filed with the Division, stating "This arrangement was made with no idea whatever of fixing or controlling the level of prices but only with the idea of preventing rebating or the granting of special concessions. . .."

Drastic provisions designed to stabilize prices are contained in House Bill No. 276, passed on March 26, r940, by the Kentucky Legislature, without the approval of the Governor. The statute provides not only for mandatory fair-trade contracts but also for the fixing of mark-ups for various classes of trade buyers. All distillers, rectifiers, blenders, wholesalers, vintners, or retailers are required by Section 2 to enter into fairtrade contracts, giving wholesalers of liquor not less than a $15 \%$ mark-up, wholesalers of wine not less than a $20 \%$ mark-up and retailers not less than a $33 \% 3 \%$ mark-up in lots less than case lots and not less than $10 \%$ in units of one case or more. Section 2(d) provides that "any donations, free goods, bribery, or rebates of any character whatsoever which constitute any part of an inducement to purchase . . . shall be construed as a violation of the minimum mark-up resale prices herein pro-

\footnotetext{
4 Alcoholic Beverage Control Act, Laws I935, c. 333, \$55.5, and Rule 42 (March, I940).

" Distilled Spirits Regulations, (Aug. 1939), General Provisions, $§$ I.

"Id. \$I3.

"7 Laws 1935, c. 226, \$32R.

${ }^{46}$ Idaho Laws I935, c. I32, \$6(5).

${ }^{4}$ Bulletin 62.
} 
vided." This provision indicates a merger of the fair-trade, the price-fixing, and anti-tied-house policies.

Mark-ups are to be computed on actual price, including all bottling charges, taxes, and transportation charges to be calculated on a minimum basis of twenty-five cents per case. Wholesalers are required to use invoices of substantially standard form and to file copies of fair-trade contracts with all retailers to whom they sell merchandise. ${ }^{40}$ "Minimum values upon which the wholesalers' mark-up must be taken" are fixed by regulation, ${ }^{50}$ in order "to make the Distilled Spirits and Wine Fair Trade Act applicable to private label merchandise."

Arbitrary minimum bottlers values are listed for products of various ages, proofs, and sizes, for the purpose of computing the wholesalers' mark-up. By this device a minimum price is established for private labels as well as for branded merchandise and bottlers of private labeled merchandise can not undermine branded merchandise by claiming low bottlers values for private brands.

Michigan, after experimenting with price posting ${ }^{51}$ and minimum prices for malt beverages, ${ }^{52}$ repealed the price-fixing provisions on January $3 \mathrm{I}$, 1940, without comment. $^{53}$ The minimum prices of wine to wholesalers and retailers, which were fixed as of October $14,1938,{ }^{54}$ have not been repealed. Wineries and wholesalers were notified on January $16,1940,55$ that sales below the minimum prices would constitute grounds for the revocation of licenses.

On July 15, 1938, the Liquor Control Commissioner of Minnesota notified all manufacturers, wholesalers, and retailers that they would be required to market their products under fair-trade contracts and that all manufacturers and owners of liquor brands were required to file with the Commissioner a list of brands and minimum ten case prices from the wholesaler to the retailer, as well as minimum resale prices to the consumer, the resale and bottle prices of the retailer to be not less than $33 \frac{1}{3} \%$ of the ten case price of the wholesaler..$^{50}$ Specific quantity discounts are permitted.

New Hampshire gives its Commission authority to investigate prices charged by wholesalers and retailers and to revoke the permit of any wholesaler or retailer after hearing if it finds "that the profit made from the sale of beverages by such permittee is unreasonable and excessive." 57

In New Jersey the Commissioner is empowered to prohibit or regulate the sale of alcoholic beverages in violation of any fair-trade contract. ${ }^{58}$ By regulation manufacturers or wholesalers who have entered into a fair-trade contract must file a copy of such contract with the Department of Alcoholic Beverage Control and must notify retailers as to the prices contained therein. ${ }^{59}$ In Gain v. Burnett, ${ }^{00}$ it was held that this regulation would be valid under the general powers of the Administrator with-

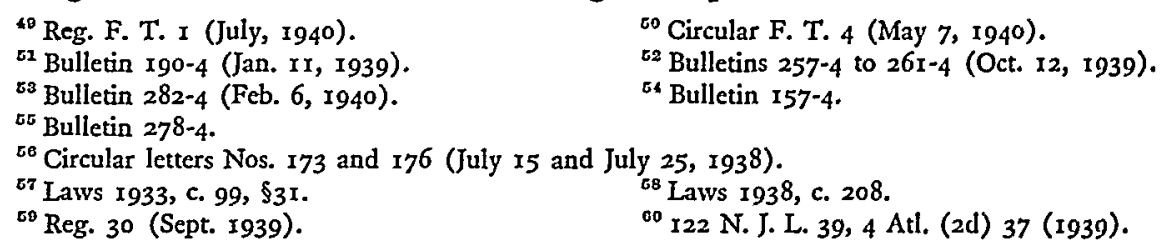


out the specific legislation in Chapter 208. It is also unlawful for any manufacturer or wholesaler to discriminate among retailers by offering discounts, rebates, free goods, allowances, or other inducements not offered to all retailers. ${ }^{61}$ The Commissioner is empowered to provide for maximum concessions of this nature.

In New Mexico the fair trade act is substantially restated with additional drastic and complex price provisions in the Liquor Control Act of $1939 .{ }^{62}$ It is provided that no beer or ale shall be sold unless uniform minimum fair-trade prices have been fixed governing the retail selling price, ${ }^{63}$ but apparently the act contains no such provision in respect to other alcoholic beverages. Section I304 provides that no fairtrade contract shall be held illegal, void, voidable, or unenforceable because it was made at the insistence or request of a wholesale liquor dealer or retail liquor dealer or an organization of wholesalers or retailers where the gross profit demanded in the retail selling price does not exceed $331 / 3 \%$ based on the retailers' price. Contracts protecting a gross retail profit in alcoholic beverages except beer in excess of $33 \frac{1}{3} \%$ based on selling price are prohibited. Section 1306 prohibits fair-trade contracts protecting a wholesaler's gross profit in spirituous liquors in excess of $184 / 100 \%$ based on the wholesaler's selling price.

Under $\$ 1406$ of the New Mexico law contracts between retailers are to be approved by the Chief of Division of Liquor Control providing the parties agree: ( $\mathrm{r}$ ) that they will sell at stipulated prices which do not permit a gross profit of more than $33 \frac{1}{3} \%$ based on the stipulated selling price or (2) that they will not buy articles which are not covered by fair-trade contracts for which minimum fair-trade prices have not been set, or (3) they will not buy articles on which minimum retail prices have not been fixed under the provisions of "This article protecting the New Mexico retail

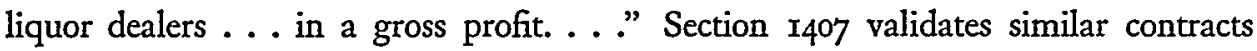
among wholesalers provided that the agreements between them do not result in a gross profit to them of more than $16 \% 3 \%$ in respect to liquor and $331 / 3 \%$ in respect to wine, based upon stipulated selling prices.

Section $14 \mathrm{ro}(\mathrm{II})$ (b) expressly prohibits the sale or offering for sale of distilled spirits, wine, and malt beverages to the retailers at less than the cost thereof "with the intent or effect of inducing the purchase of other merchandise or of unfairly diverting trade from a competitor, or of otherwise injuring a competitor. . .." The statute elaborately defines cost of spirituous liquor to include taxes and incidental costs, plus either the purchase price or replacement cost, plus a mark-up "amounting to less than the minimum cost of operation in the handling of spirituous liquors at wholesale by the most efficient wholesale liquor dealer, which mark-up, in the absence of satisfactory proof to the contrary, made by the wholesaler before the sale to Chief of Division, ... shall be $1751 / 100 \%$." The "net cost of wine to wholesalers" is similarly defined except that the mark-up in the absence of proof to the contrary is $34 \%$. The prima facie mark-up used to determine the cost of spirituous liquor to the retailer

${ }^{01}$ Laws I939, c. 87 .

${ }^{02}$ Laws I939, c. 236 , arts. XIII, XIV. ${ }^{03}$ Id. $\$ 1303$. 
and the cost of wine to the retailer is fixed at $38 \% 10 \%$. The cost of beer to the wholesaler in the absence of proof to the contrary includes a mark-up of $20 \%$. The cost of beer to the retailer in the absence of such proof includes a mark-up of $25 \%$. Regulations No. 15 relating to minimum price contain elaborate requirements for establishing minimum cost of operation "less than the prima facie minimum cost of operation fixed by the statute."

The effect of Sections I 406 and ${ }_{4} 407$ is to permit horizontal price agreements below a stipulated maximum gross profit. The effect of Section I4ro is to prohibit sales below cost, including in the definition of cost an arbitrary mark-up over purchase or replacement cost to cover cost of doing business. The statute has the following unusual and drastic provisions: (I) It requires all beer to be sold under fair-trade contracts, while not requiring all liquor to be sold under such contracts, (2) it specifically permits groups of retailers to force vendors to sell under fair-trade contracts, (3) it places maximum limits upon the gross profits permissible under the fairtrade contracts, (4) it permits horizontal contracts among retailers and among wholesalers fixing uniform gross profits below certain maximums, and (5) it prohibits sales below cost, fixing arbitrary mark-ups, as cost of doing business, to be added to purchase or replacement cost of the article. ${ }^{64}$

North Dakota requires wholesalers to post prices to retailers as a tax rather than a price control measure. ${ }^{65}$

In Oregon wine must be sold pursuant to fair-trade contracts. ${ }^{60}$ Persons selling beer for resale must abide by prices posted with the Commission, ${ }^{67}$ while persons selling wine for resale may not sell below posted minimum prices. ${ }^{68}$ At least one fair trade contract covering all brands must be made by a wine wholesaler who must notify all retailers. ${ }^{69}$

In Rhode Island the Division of Intoxicating Beverages has the power to fix wholesale prices of all intoxicating liquors. ${ }^{70}$ By regulation ${ }^{71}$ they are required to charge a price which will give them a gross profit of $15 \%$, which price must be posted with the Liquor Control Administrator. The regulations specifically prohibit free goods, but provide for specified quantity discounts.

South Carolina requires that all brands be sold under fair-trade agreements and prohibits a wholesaler or retailer from possessing any brand not covered by such agreements. $^{72}$ Quantity discounts are specified. ${ }^{73}$

The Washington Liquor Control Board requires brewers and beer importers to post wholesale prices for all brands in various zones fixed by the Board. ${ }^{74}$ Wineries

\footnotetext{
${ }^{e}$ It is to be noted that the gross profits which wholesalers and retailers are allowed to agree upon and demand are based upon their sales prices while the prima facie mark-up used as an arbitrary cost of operation is based upon purchase prices.

${ }^{60}$ Reg. 6, $\S_{5}(\mathrm{e})$.

${ }^{68}$ Reg. 10 B.

${ }^{\circ 5}$ Laws 1939, c. 242, \$3.

${ }^{\text {oz Reg. }}$ io $A$.

${ }^{60}$ Circular letter (Junc 7, 1940).

${ }^{70} \mathrm{C} .{ }_{164}, \S 6$, as amended by Senate Bill 232, (Apr. 27, 1940).

${ }^{71}$ Reg. 72 (July, 1937, amended Mar. 17, 1939).

${ }^{72}$ Reg. 6 (June 27, 1939).

${ }^{73}$ Reg. 7 (June 27, 1939).

"Reg. 49 (Oct. I, I939).
} 
must also post prices but no zones are created. ${ }^{75}$ Brewers and wineries are required to file a copy of all written transactions and memoranda of all oral agreements with their wholesalers relative to the terms of sales, discounts, advertising allowances, bonuses, or gifts. The granting of any quantity discounts even though posted ${ }^{76}$ is prohibited.

In an opinion dated October 14, 1935, the Attorney General of Wisconsin upheld the plan under which the Wisconsin State Brewers Association, under contract with its members, required the filing of prices and the posting of a five cents per barrel performance guarantee. He said that the Association plan was "designed to have a stabilizing influence upon the industry without restraining competition."

Through this patchwork price legislation three threads may be traced: ( $\mathrm{r}$ ) an effort to make effective the tied-house legislation prohibiting discrimination among retailers, (2) an effort to stabilize prices primarily for the benefit of the retailer, and (3) an effort to protect the property interest in the brand name. The third thread, which alone has sustained the validity of the statutory right of action against the non-contracting retailer under the fair-trade acts is barely discernible in the price legislation in and its application to the liquor industry. Retailers are the real beneficiaries. Even in those states where there has been no "unfair practice" legislation fixing mark-ups, the fair-trade acts have had this result. ${ }^{77}$

The Chairman of the Federal Trade Commission in an address before the $\mathrm{Na}$ tional Wholesale Druggists' Association Convention on October 4, r937, warned that even under the Miller-Tydings Act "resale price maintenance agreements among competing manufacturers or among competing distributors, are not permissible if the parties are engaged in interstate commerce or their dealings directly affect interstate commerce." Horizontal price agreements between producers or between wholesalers or between retailers are specifically exempted from protection under the usual fairtrade acts yet it has been seen that they are specifically permitted in some of the more drastic legislation relating to liquor. Whether such legislation, if it burdened interstate commerce, would be sustainable even since the Twenty-first Amendment, is debatable.

Since the fair-trade acts permit the fixing of vertical prices, a horizontal agree-

${ }^{75}$ Reg. 8 I (Oct. I, I939).

${ }^{76}$ Bulletin 19 (Nov, $17, x 936$ ).

${ }^{77}$ That the industry in practice has lost sight of the theory underlying the fair-trade acts; i.e., the protection of the property interest in the brand name, was revealed in the hearings before the Temporary National Economic Committee of Congress in its investigation of concentration of economic power. Mr. W. W. Wachtel, President of Calvert Distillers Corp., which, as a matter of policy, engages extensively in fair-trade contracting, stated (T.N.E. C. Hearings, supra note 23 at 2565): "It isn't politics, it is a question of misunderstanding of who benefits from fair trade. The retailer benefits, not the distiller. You pull the plug out tomorrow on Calvert and our sales would double, but we don't think it would be good over the long pull because the retailer would go broke." Mr. Wendell Berge, Special Assistant to the Attorney General, asked Mr. Wachtel (at 2563), "In other words, you take into account, or try to take into account, in fixing the price what you deem to be the retailer's welfare. If you think he can exist on one price you fix it there, and if you think that he requires a higher price you fix it there." Mr. Wachtel, "That is right." There was considerable discussion at the hearing as to the tendency under the fair-trade acts towards the fixing of price to the detriment of the consumer. See also Edwards, Appraisal of "Fair Trade" and "Unfair Practice" Acts, abstracted in (1940) 30 Am. Econ. Rev. No. r, pt. 2, Supp. ir2. 
ment, either among producers or among retailers, would freeze the entire price structure and completely eliminate competition in possible violation of many state antitrust laws and federal laws. There is evidence that this is happening in the liquor industry. The fair-trade acts designed to protect the property interest of the manufacturer in the trade-mark or brand name have turned out to be a blackjack in the hands of retailers. The Federal Trade Commission issued a complaint on January 20, 1940, against the National Retail Liquor Package Stores Association, 29 other retail liquor associations, 83 individuals and, through representatives, all members of the various associations, as a class, alleging that the defendants had agreed and conspired to eliminate price competition among themselves for the purpose of increasing their profits. It is charged that the defendants in order to make effective the conspiracy not only fixed prices among themselves but also "under threat of boycott" sought to compel manufacturers, importers and wholesalers to sell at prices fixed by the defendants by insisting that they enter into fair-trade contracts. It is further alleged that they spied upon retailers, reported price cutters to their vendors and by threat of boycott demanded that they refuse to supply them. It is alleged that by these acts the retailers had created a monopoly and that their acts constitute unfair competition within the meaning of the Federal Trade Commission Act.

A similar condition is revealed in the defense filed in the case of Julius Weisstein v. Irving Silverman now pending in the Supreme Court of New York. ${ }^{78}$ Silverman, accused of price cutting, alleges in his defense that plaintiff, a retailer, and Chairman of the Distillers Committee of the Greater New York Licensed Liquor Stores Association, Inc., had conspired with other retailers and members of associations doing ninety percent of the package store business in the New York area to fix a 40 percent mark-up for themselves on domestic liquors and a $331 / 3$ percent mark-up on imported liquors in violation of the state anti-trust laws. It is alleged that they had by boycott forced manufacturers to enter into contracts giving them uniform mark-ups.

The issue raised by the cases is critical. If groups of retailers through horizontal agreements and boycotts can force vendors to give them uniform mark-ups, there is complete freezing of the price structure at levels limited only by the greed of the powerful pressure groups. While some of the state laws specifically permit such horizontal agreements in the alcoholic beverage field and specifically permit boycotts against manufacturers who refuse to furnish the vertical support to complete the rigid price structure, the statutes fix a maximum in the interest of the consumer. If such rigidity is desirable in the interest of preventing price wars, it should be accomplished by legislation adequately protecting the consumer and not by the dictation of pressure groups. The resale price maintenance contract, originally purporting to protect the property interest of the producer in brand names, has proved to be a dangerous weapon in the hands of the retailer.

Out of the experiments in price legislation in the alcoholic beverage industry may come a plan which will serve to further the policy against the tied-house, prevent

${ }^{78}$ N. Y. Times, Aug. 23, 1940, p. 22, col. 4 . 
discrimination, protect the property right of the manufacturers in their brand names, assure the retailer a reasonable mark-up, prevent destructive price wars and at the same time protect the consumer. The use of contracts which are not really contracts, for purposes foreign to the theory on which they were sustained, in a highly competitive industry, which is fraught with inherited evils and which deals in a socially dangerous commodity offering big profits, does not appear to be the answer.

\section{WAREHOUSE RECEIPTS}

The question has frequently arisen as to whether the statutes governing the conduct of manufacturers, importers, and wholesalers are applicable to dealers in warehouse receipts and whether such dealers are subject to the various statutes governing the sale of securities. There is little uniformity in the treatment of the subject.

Warehouse receipts play an important function in the liquor industry, because whiskey must be stored for long periods necessitating large amounts of frozen capital. It has been the practice to borrow on the immature whiskey in the warehouses, issuing warehouse receipts to the creditors. They also serve as the media through which manufacturers and rectifiers deal in bulk whiskey.

Section 6 of the Federal Alcohol Administration Act prohibits the sale of distilled spirits in bulk to wholesalers, retailers, and consumers and provides that warehouse receipts for bulk whiskey must contain provisions limiting the delivery of the spirits covered thereby to qualified persons; namely, distillers, rectifiers, and a few other types of persons.

It was commonly supposed by the uninformed public at the time of Repeal that enormous profits were to be made in the liquor business. The result was that persons wholly unfamiliar with it were an easy prey for unscrupulous individuals who sought to sell warehouse receipts to consumers and to retailers at prices far above their worth. The prices quoted appeared to the uninitiated to be extremely low because they did not cover storage, taxes, bottling, and other incidental expenses which the purchaser must meet before he could obtain physical possession of the spirits covered by the receipt. Small retailers were particularly gullible and in many cases purchased receipts in large quantities at prices which they considered bargain prices only to find when withdrawal time came that they could buy better and more saleable whiskey at much lower prices. Frequently fraudulent representations were made. ${ }^{79}$

Because a great majority of warehouse receipts are sold in interstate commerce and because they are essential to the distilling industry, much confusion would be avoided if they were treated uniformly by the legislative and administrative bodies. Such, however, is not the case. In fourteen states the sale of the receipt is equivalent to the sale of liquor. ${ }^{80}$ In ten states they have been held to be securities, ${ }^{81}$ while seven states have held that they are not securities. ${ }^{82}$ Sales to the public are prohibited in

${ }^{70} \mathrm{New}$ York Joint Legislative Committee on Interstate Co-operation and the Council of State Governments, Interstate Conference on Liquor Control, Jan. r940, Transcript of Proceedings, p. 21 .

${ }^{80}$ Ala., Ariz., Calif., Colo., Conn., Iowa, La., Mich., Mo., N. J., N. Y., Pa., Wash., Wis.

${ }^{82}$ Fla., Ind., Ky., La., Minn., Neb., N. D., Ohio, Ore., Wis.

${ }^{82}$ Ariz., Mll., Mass., N. M., Okla., Pa., Wash. 
eight states. ${ }^{83}$ The sale of warehouse receipts is equivalent to the sale of the whiskey covered thereby for the purpose of federal permits and occupational taxes.

California requires broker licenses except in the case of sales by a manufacturer, rectifier or wholesaler or by a financial institution. ${ }^{84}$ In Michigan receipts may be sold only by the distiller of the whiskey covered thereby or his agent. ${ }^{85}$ Their sale has been held to be illegal in Oregon as the receipt represents the whiskey and the state has the exclusive right to sell. ${ }^{86}$ In a number of states licenses are required by the securities commissions.

A proposed uniform statute was adopted by the Interstate Conference on Liquor Control called by the New York Joint Legislative Committee on Interstate Co-operation and the Council of State Governments held in Buffalo in January, I940. It provides:

"No licensee shall sell or purchase any receipts, certificates, contracts or other documents issued for the storage of alcoholic beverages except as provided by the rules of the liquor authority. The liquor authority shall prescribe such rules for the purchase and sale of such receipts, certificates, contracts or other documents issued for the storage of alcoholic beverages which, in its opinion, will best accomplish

(I) Elimination of fraudulent and deceptive transactions;

(2) Protection of purchasers against defaults by sellers;

(3) The delivery of the alcoholic beverages represented by such receipts or documents, and

(4) The payment of all taxes due thereon to the state.

This act shall take effect immediately."

Uniformity will probably be difficult to obtain because the subject traverses two fields of established law, liquor legislation and securities legislation, and because warehouse receipts have been the subject of diversified treatment over a period of years.

${ }^{83}$ Ala., Conn., Mass., Mich., N. C., Okla., Ore., Wis.

${ }^{84}$ Laws I935, c. 330, \$6(k). ${ }^{85}$ Reg., May 4, 1937.

${ }^{80}$ Opinion, Dec. 10, 1934, Bien. Rep. Att'y Gen. (1934-1936) 165. 